\title{
Inhibition of food-stimulated gastric acid secretion by cimetidine
}

\author{
R. E. POUNDER ${ }^{1}$, J. G. WILLIAMS, R. C. G. RUSSELL ${ }^{2}$, \\ G. J. MILTON-THOMPSON, AND J. J. MISIEWICZ \\ From the Medical Research Council Gastroenterology Unit, Central Middlesex Hospital, London, \\ Royal Naval Hospital, Stonehouse, Plymouth, Devon, and St. Mary's Hospital, London
}

SUMMARY The effect of cimetidine, a new histamine $\mathrm{H}_{2}$-receptor antagonist, on gastric acid secretion stimulated by a homogenised meal was studied in six normal volunteers using an in vivo intragastric titration technique. The subjects were studied twice, no more than $48 \mathrm{~h}$ apart, receiving either cimetidine $200 \mathrm{mg}$ or placebo in random order. Cimetidine administered either 32 min before (three subjects) or with the meal (three subjects) significantly inhibited gastric acid secretion in all the subjects throughout the period of study; $96 \mathrm{~min}$ after food, total acid secretion decreased by 67 and $57 \%$ respectively. When the drug was taken with the meal absorption was slower (mean peak blood level $2 \cdot 34 \mu \mathrm{mol} / 1,80-128 \mathrm{~min}$ after dosing) than when administered on an empty stomach (mean peak blood level 5.08 $\mu \mathrm{mol} / 1,48-64 \mathrm{~min}$ after dosing). Blood cimetidine concentration correlated significantly $(\mathrm{P}<0.01)$ with percentage inhibition of acid output and the calculated concentration resulting in $50 \%$ inhibition of gastric acid secretion $\left(\mathrm{IC}_{50}\right)$ was $1.6 \mu \mathrm{mol} / \mathrm{l}$. Secretion of gastrin in response to food was unaffected by cimetidine. The results suggest that $200 \mathrm{mg}$ cimetidine effectively inhibits food-stimulated acid secretion and that the bioavailability of the drug may be affected by the timing of dosage in relation to meals. No unwanted effects were observed.

Cimetidine is a new histamine $\mathrm{H}_{2}$-receptor antagonist which differs from metiamide by having a cyanoguanidine group in place of the thiourea group in the side-chain (Black et al., 1972; Brimblecombe et al., 1975) (Fig. 1). Preliminary studies have suggested that cimetidine is slightly more potent than metiamide in inhibiting human gastric acid secretion stimulated by pentagastrin or histamine (Burland, et al., 1975). We have used in vivo intragastric titration to study the effect of oral cimetidine on foodstimulated gastric acid secretion in normal subjects.

\section{Methods}

Food-stimulated gastric acid secretion was measured using a modified form of the technique described by Fordtran and Walsh (1973).

All the meals were prepared in advance from the same batch of food, homogenised, and stored at

\footnotetext{
${ }^{1}$ Address for reprints: R. E. Pounder, M.R.C. Gastroenterology Unit, Central Middlesex Hospital, London, NW10 7NS.

2Present address: The Middlesex Hospital, London.

Received for publication 3 December 1975
}

$-20^{\circ} \mathrm{C}$. Each meal contained $100 \mathrm{~g}$ lean roast beef, $30 \mathrm{~g}$ bread, $10 \mathrm{~g}$ butter, and $1 \mathrm{~g}$ salt made up to $450 \mathrm{ml}$ with water. The composition of the meal (derived from McCance and Widdowson, 1960) was protein $29.0 \mathrm{~g}$, carbohydrate $15.8 \mathrm{~g}$, fat $23.9 \mathrm{~g}$, energy value $1,667 \mathrm{~kJ}$. The meals were warmed to $37^{\circ} \mathrm{C}$ and the pH adjusted to 5.50 with less than 1 $\mathrm{ml}$ concentrated hydrochloric acid immediately before use.

The subjects fasted overnight and on the day of the test were intubated with a double lumen 14 FR nasogastric tube (Salem Sump, Sherwood Medical Industries Inc., Argyle) the tip of which was positioned under $x$-ray control to the most dependent part of the stomach. After emptying the stomach, the test meal was instilled through the larger lumen of the tube during five minutes. The experiments continued until it became impossible to aspirate at least $50 \mathrm{ml}$ gastric contents despite turning the subject from side to side.

Throughout each study the gastric contents were mixed by the aspiration and return of $50 \mathrm{ml}$ of the meal every 15 seconds. In addition, the subjects moved from the supine to the left or right decubitus 

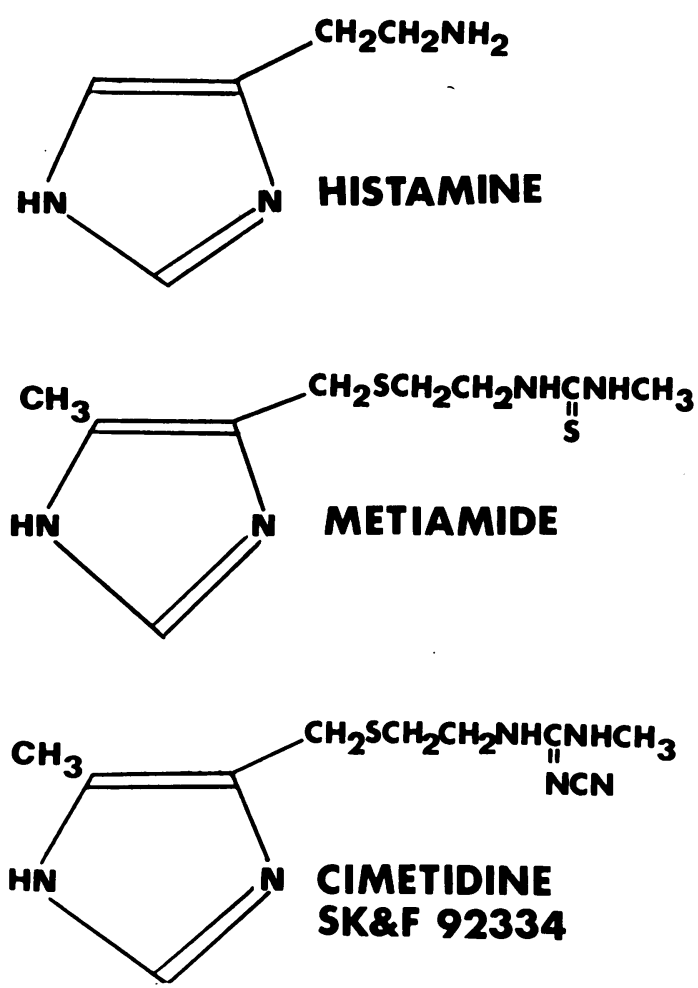

Fig. 1 Formulae of histamine, metiamide, cimetidine.

position for a short time every $16 \mathrm{~min}$. The $\mathrm{pH}$ of the gastric contents was recorded to the nearest $0.01 \mathrm{pH}$ unit using a combined glass electrode (Radiometer, Copenhagen) every 2 min throughout the experiment. This $\mathrm{pH}$ was measured on $5 \mathrm{ml}$ aspirates which were returned to the stomach immediately after the measurement. The electrode was kept at $37^{\circ} \mathrm{C}$ in a buffer of pH 5.4 and calibration was checked before each reading.

The intragastric $\mathrm{pH}$ was maintained at 5.50 by adjusting the rate of a sodium bicarbonate infusion using a variable speed pump (Watson Marlow Flow Inducer MHRE 22/Delta, Falmouth). The sodium bicarbonate was infused through the smaller lumen of the nasogastric tube at a concentration of 333 $\mathrm{mmol} / \mathrm{l}$ for the cimetidine and $666 \mathrm{mmol} / \mathrm{l}$ for the placebo studies. Every 16 min the volume of sodium bicarbonate added to the stomach was read to the nearest $0 \cdot 1 \mathrm{ml}$ from a burette reservoir connected to the pump. The amount of acid secreted was assumed to be equal to the mmol of sodium biarbonate required to maintain the $\mathrm{pH}$ of the gastric contents at $5 \cdot 50$.

Venous blood was withdrawn through an indwelling cannula kept patent with heparinised
$0.9 \%$ sodium chloride. Serial samples for basal values were obtained before food or drugs were placed in the stomach, and at every $16 \mathrm{~min}$ thereafter. Whole blood cimetidine concentration $(\mu \mathrm{mol} / \mathrm{l})$ was determined on duplicate samples using high pressure liquid chromatography (Smith Kline Corporation, Philadelphia). Plasma gastrin was measured by radioimmunoassay using an antibody raised to synthetic human gastrin I conjugated to bovine serum albumin by carbodiimide. The antibody reacted $100 \%$ with human little gastrin and $75 \%$ with human big gastrin, reacting preferentially with the C-terminal end of the molecule. There was less than $1 \%$ cross-reactivity with cholecystokinin or pentagastrin. The assay used gastrin-free plasma prepared by affinity chromatography to make up the standards (MRC 68/439) and could detect differences of $2 \mathrm{pg} / \mathrm{ml}$ gastrin I with $95 \%$ confidence.

Six normal subjects (mean age $31.5 \mathrm{yr}, \mathrm{SEM} \pm$ $3 \cdot 5$, range $20-43$; mean weight $78 \cdot 2 \mathrm{~kg}, \mathrm{SEM} \pm 5 \cdot 4$, range 53-88) were each studied on two occasions, no more than two days apart. One normal female subject was studied twice without medication in order to check the reproducibility of the method. The six males received either cimetidine solution (200 mg in $4 \mathrm{ml}$ ), or placebo (water, $4 \mathrm{ml}$ ) in random order and without knowledge of the sequence of treatment. The $\mathrm{pH}$ of the cimetidine solution was 5.30 and titration of $4 \mathrm{ml}$ of the solution to $\mathrm{pH} \mathrm{5.50}$ required only $0.02 \mathrm{mmol}$ of sodium hydroxide. Three subjects received the test substance mixed with the meal; in the other three the placebo or cimetidine were placed in the stomach in $50 \mathrm{ml}$ water $32 \mathrm{~min}$ before the meal. In these subjects the stomach was emptied before the administration of the test substance and not immediately before the infusion of the test meal.

Haematological and biochemical safety profiles were performed before and after the studies. All subjects gave their informed consent to the procedures, which were approved by the appropriate ethical committees.

\section{Results}

The adjustments of the rate of the sodium bicarbonate infusion were successful in maintaining the intragastric $\mathrm{pH}$ close to the set level of $5 \cdot 50$. Figure 2 shows that the $\mathrm{pH}$ of the gastric aspirates obtained at the end of each 16 min period was between 5.45 and 5.55 in $47 \%$ of these samples, and between 5.35 and 5.65 in $84 \%$. Turning the subject from side to side was important in ensuring adequate mixing of gastric contents, the $\mathrm{pH}$ dropping by $0 \cdot 10-0.20$ after each turn; these swings of $\mathrm{pH}$ were easily corrected by temporarily increasing the rate of the bicarbonate 


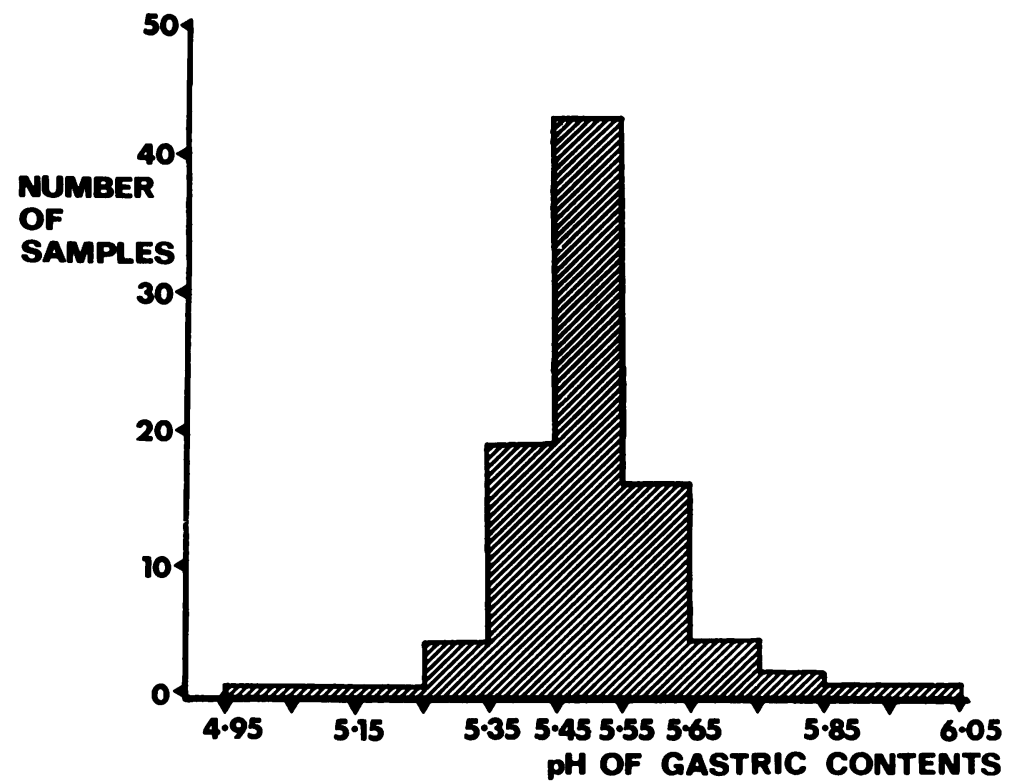

Fig. 2 pH of gastric aspirates obtained at the end of $16 \mathrm{~min}$ observation periods in duplicate studies on seven subjects.

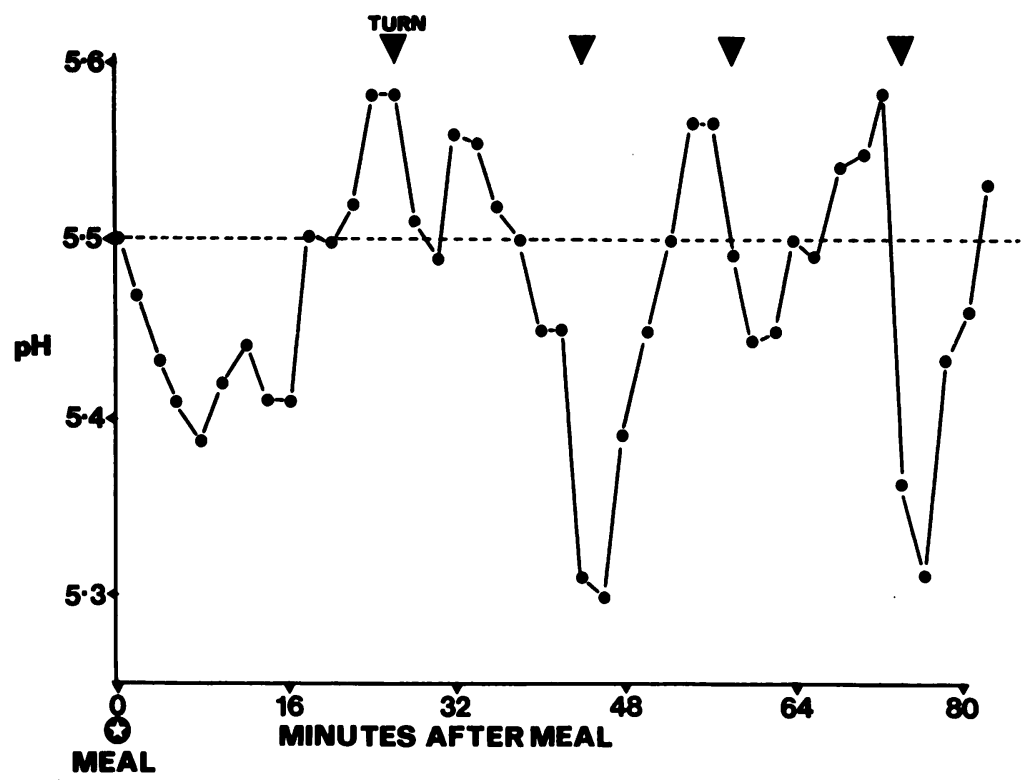

Fig. 3 Effect of turning to left and right decubitus on $\mathrm{pH}$ of gastric aspirates in one subject.

infusion (Fig. 3). Replicate studies in the one subject without medication (Fig. 4) showed a good correlation for the rate of acid secretion $(r=0.99$, $P<0.01)$ and for the amount of acid secreted (slope $=0.87$ ). In the six male subjects the volume of bicarbonate infused averaged $82.6 \pm 9.5 \mathrm{ml}$ (SEM) of the $666 \mathrm{mmol} / 1$ solution in the placebo experiments and $62.5 \pm 8.9 \mathrm{ml}$ of the $333 \mathrm{mmol} / \mathrm{l}$ solution in the cimetidine experiments.

The cumulative acid secretion of each subject is shown in Fig. 5; Table 1 shows the mean output and percentage inhibition in the six subjects during each $16 \mathrm{~min}$ of the test. Cimetidine significantly inhibited food-stimulated acid secretion in all the 

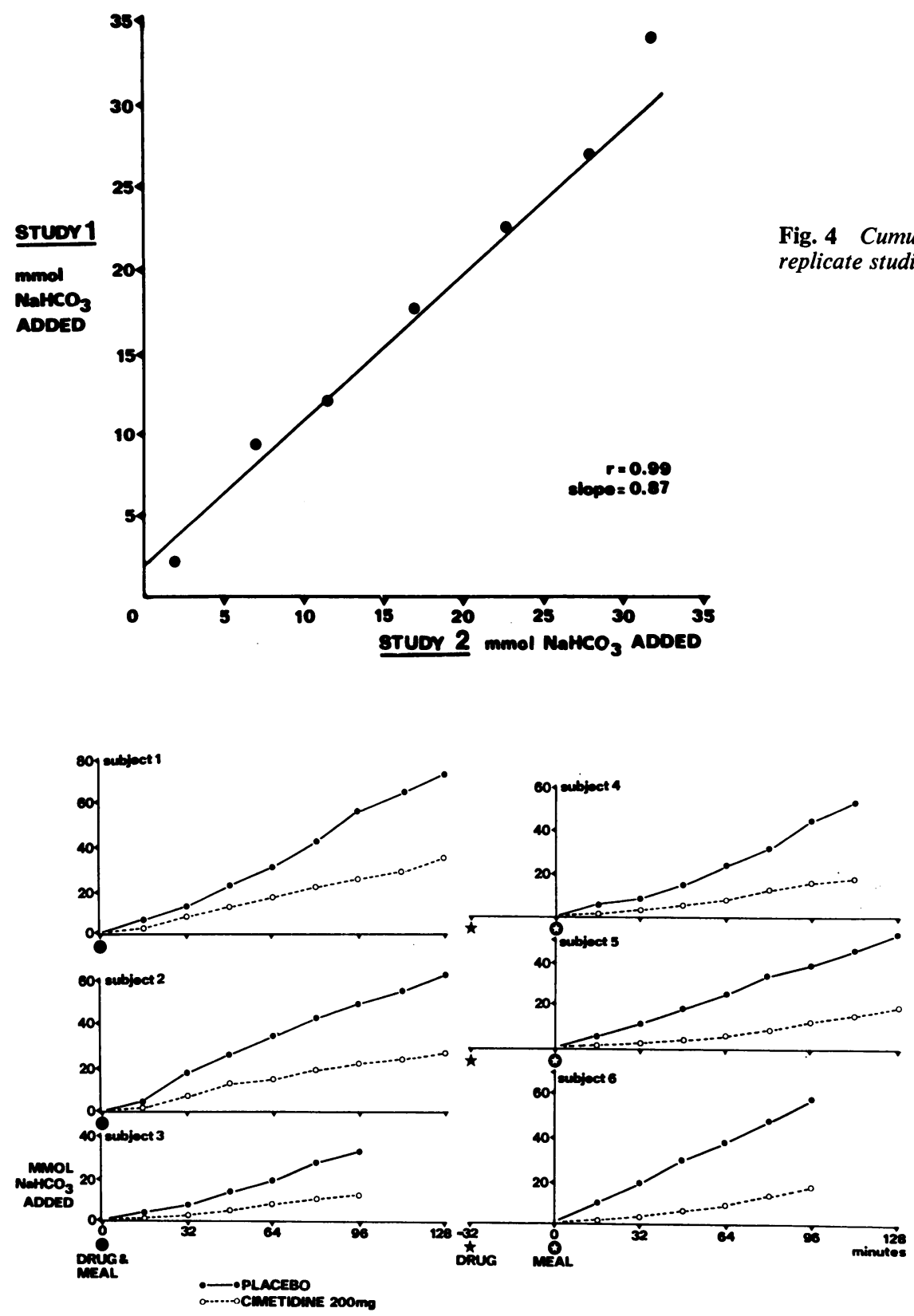

Fig. 4 Cumulative acid secretion in replicate studies on the same subject.
Fig. 5 Cumulative acid secretion: cimetidine $200 \mathrm{mg}$ or placebo in six subjects. Drug with meal (left) and before meal (right). subjects during all the periods of observation $(\mathrm{P}<$ 0.01 ; analysis of variance). In the three subjects given cimetidine with food, mean acid secretion was decreased by $57 \%$ of the control output during the $96 \mathrm{~min}$ after the drug, and by $60 \%$ during $112 \mathrm{~min}$ in the two subjects in whom measurements were possible for a longer time. When cimetidine was given 32 min before the meal, mean acid secretion was decreased by $67 \%$ of control output at $96 \mathrm{~min}$ (three subjects) and by $65 \%$ at $112 \mathrm{~min}$ (two subjects).

Blood cimetidine levels were markedly affected by the time of administration of the drug in relation to the meal. Peak concentrations of the drug were 


\begin{tabular}{|c|c|c|c|c|c|c|}
\hline \multicolumn{7}{|c|}{ Mean $( \pm S E M)$ acid secretion mmol/16 min (\% inhibition) } \\
\hline \multicolumn{7}{|l|}{ With meal $(n=3)$} \\
\hline Placebo & $4.5 \pm 0.5$ & $7 \cdot 6 \pm 2 \cdot 7$ & $7.9 \pm 0.7$ & $8 \cdot 1 \pm 1 \cdot 1$ & $8 \cdot 6 \pm 1 \cdot 1$ & $8 \cdot 8 \pm 3.0$ \\
\hline \multicolumn{7}{|c|}{32 minutes before meal $(n=3)$} \\
\hline Placebo & $7 \cdot 1 \pm 1.6$ & $6.4 \pm 1.4$ & $7 \cdot 7 \pm 1 \cdot 4$ & - $7.5 \pm 0.9$ & $8.1 \pm 0.9$ & $8.8 \pm 1.6$ \\
\hline Cimetidine & $\begin{array}{l}1.0 \pm 0.5 \\
(-86 \%)\end{array}$ & $\begin{array}{l}2 \cdot 3 \pm 0.4 \\
(-64 \%)\end{array}$ & $\begin{array}{l}1.9 \pm 0.5 \\
(-76 \%)\end{array}$ & $\begin{array}{l}3 \cdot 0 \pm 0 \cdot 1 \\
(-60 \%)\end{array}$ & $\begin{array}{l}3.5 \pm 0.2 \\
(-57 \%)\end{array}$ & $\begin{array}{l}3.5 \pm 0.4 \\
(-60 \%)\end{array}$ \\
\hline Minutes elapsed after meal & 16 & 32 & 48 & 64 & 80 & 96 \\
\hline
\end{tabular}

Table 1 Mean $( \pm S E M)$ acid secretion (minol) and \% inhibition in each 16 min observation period $(n=$ number of subjects)

approximately twice as high and occurred earlier when the drug was given before the meal. At 80 min after the meal the cimetidine blood levels were similar in the two groups of subjects, but appeared to be declining in those given the drug before the meal, while the concentration curves in the other group suggest the formation of a plateau (Fig. 6).

In Fig. 7 the percentage inhibition of acid secretion in the six subjects is plotted against their calculated average blood cimetidine levels for each $16 \mathrm{~min}$ period. In all three subjects who received cimetidine with the meal, the inhibition of acid output during the first $16 \mathrm{~min}$ of the test appeared to be inappropriately high in relation to the low blood levels of the drug at that time. Regression analysis was therefore performed omitting those three results.

In both groups of subjects there was significant correlation between cimetidine blood level and percentage inhibition of acid output (drug before meal $r=0.40, \mathrm{P}=0.05$; drug with meal $r=0.72$, $P<0.01)$. Analysis of variance showed no significant difference between the slopes of the two regression lines. The regression line in Fig. 7 has therefore been calculated using the combined data of both groups, and it shows significant correlation between blood concentrations and response $(r=$ $0.56, \mathrm{P}<0.01)$. The calculated blood concentration of cimetidine resulting in $50 \%$ inhibition of foodstimulated acid secretion $\left(\mathrm{IC}_{50}\right.$ ) is $1.6 \mu \mathrm{mol} / 1$.

Immunoreactive plasma gastrin levels increased in response to the meal in both groups of subjects. Administration of cimetidine had no effect on the secretion of gastrin (Fig. 8). Cimetidine did not appear to alter the rate of gastric emptying, as estimated by the length of time after the meal during which it was possible to aspirate $50 \mathrm{ml}$ of the gastric contents. No unwanted clinical or laboratory effects were observed in any subject.

\section{Discussion}

The technique of in vivo intragastric titration (Fordtran and Walsh, 1973) was used in this $2^{*}$ study because it is eminently suitable for measuring the effects of ingested drugs on gastric acid secretion stimulated by food. As the gastric contents are left in situ and gastric secretion is not stimulated by pharmacological agents, the effects of medication, the response of gastrointestinal polypeptide hormones, and the absorption characteristics of drugs can all be studied in conditions which approximate to the physiological. This study confirms the original observations of Fordtran and others (Fordtran and Walsh, 1973; Richardson et al., 1975; Richardson et al., submitted for publication) that the technique is easy to perform, is well tolerated by the subjects,

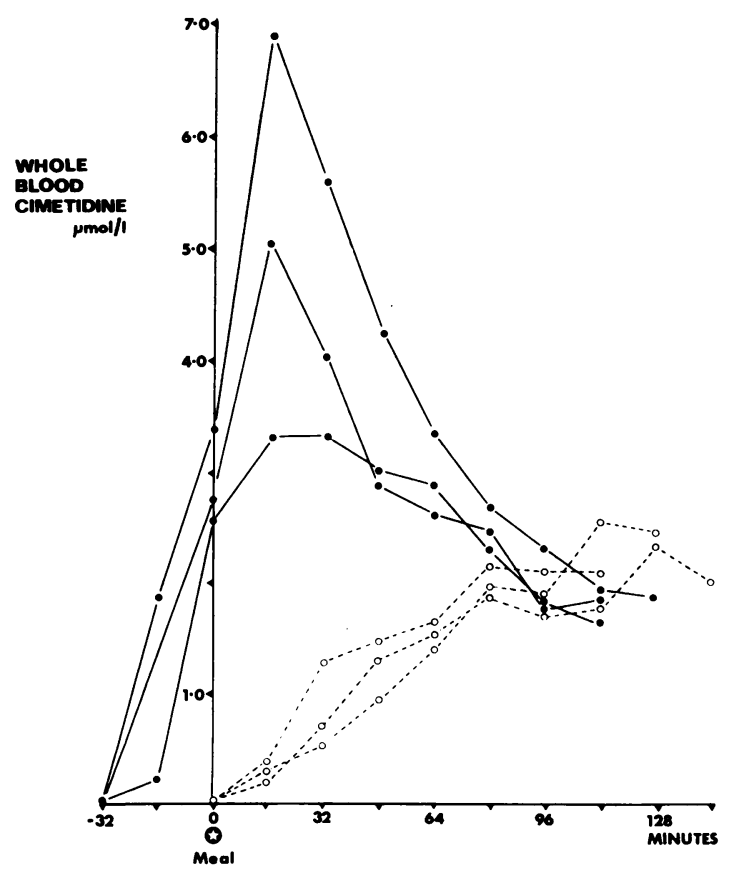

Fig. 6 Blood levels of cimetidine in individual subjects. Cimetidine before meal. ... Cimetidine with meal. 


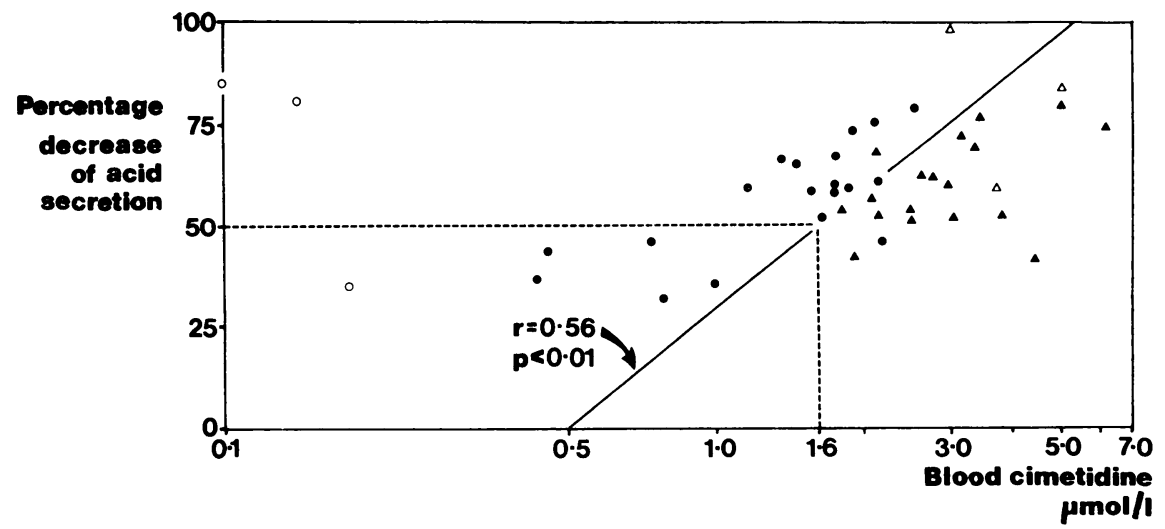

Fig. 7 Percentage inhibition of acid secretion and average blood cimetidine level for each 16 min period. $(\mathbf{O}=$ drug with meal; $\boldsymbol{\Lambda}=$ drug before meal; open symbols $=$ first $16 \mathrm{~min}$ observation period. Average blood cimetidine levels were calculated by taking the mean of blood cimetidine concentrations measured at the beginning and end of each observation period).

and gives reproducible results in replicate experiments. We were not able to measure acid secretion beyond 96 to $128 \mathrm{~min}$ after the instillation of the $450 \mathrm{ml}$ meal into the stomach. The $600 \mathrm{ml}$ meal used by Fordtran and Walsh (1973) allowed observa-

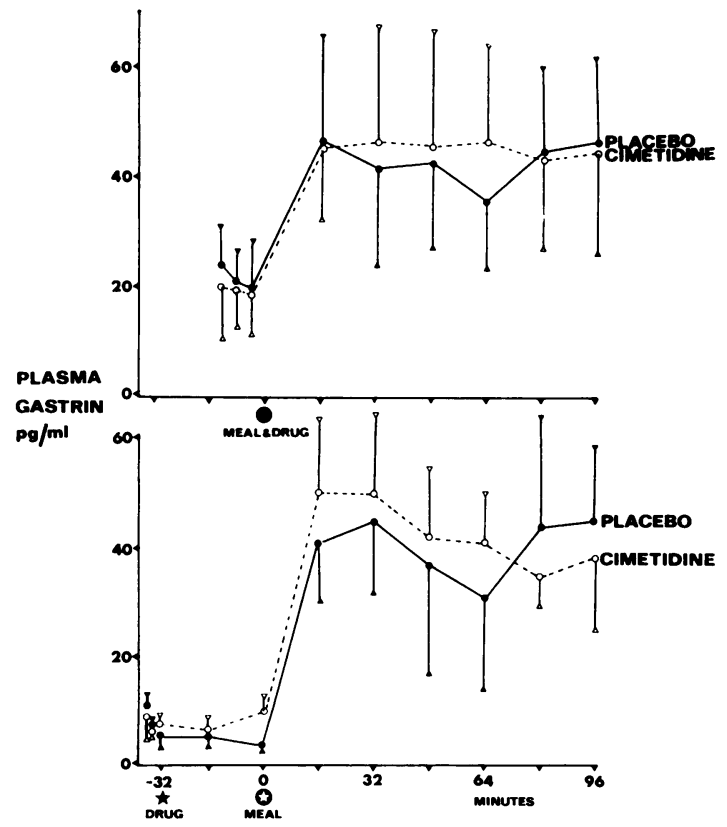

Fig. 8 Mean plasma gastrin levels ( \pm SEM) in subjects given cimetidine or placebo with meal (upper graph), and 32 minutes before the meal (lower graph). tions to be made during a longer period and therefore the large volume may be preferable for more prolonged studies of drug action. By using a more concentrated sodium bicarbonate solution with the placebo, the volumes of alkali infused were comparable in the paired experiments.

Results of this study show that 200 mg cimetidine instilled into the stomach significantly inhibited acid secretion in every subject investigated. The effect was apparent in all six subjects within $16 \mathrm{~min}$ of the meal, and there was no diminution of drug action in the 96 to $128 \mathrm{~min}$ after the meal. The present results are compared in Table 2 with four other studies reporting the effect of $\mathrm{H}_{2}$-receptor antagonists on food-stimulated acid secretion. The ID $_{50}$ of cimetidine (the dose required to produce $50 \%$ inhibition) against histamine stimulated acid secretion is lower than the ID $_{50}$ of metiamide in several animal models (Brimblecombe et al., 1975), but comparisons with other human studies must be made with caution, partly because of variations in the methods used by different investigators, and partly because patients with duodenal ulcer may secrete at a much higher rate, and at a higher fraction of the maximal histamine response, than normal subjects (Fordtran and Walsh, 1973).

The $\mathrm{IC}_{50}$ of intravenously administered cimetidine against histamine- or pentagastrin-stimulated gastric acid secretion in man has been reported to be 2.0 $\mu \mathrm{mol} / \mathrm{l}$ (Burland et al., 1975), but the present study gives a slightly lower figure of $1.6 \mu \mathrm{mol} / \mathrm{l}$ for foodstimulated secretion and oral cimetidine.

Our results show that cimetidine absorption from the gut is greatly affected by the timing of the dose in relation to the meal. Giving the drug before the 


\begin{tabular}{|c|c|c|c|c|c|}
\hline Author & Subjects & $(n o)$ & Time of dose ( $\mathrm{min})$ & Dose $(\mathrm{mg})$ & $\begin{array}{l}\text { Acid secretion } \\
(\% \text { decrease at } 90 \mathrm{~min})\end{array}$ \\
\hline \multicolumn{6}{|l|}{ Metiamide } \\
\hline Mainardi et al. (1974) & Duodenal ulcer & 6 & -30 & $\begin{array}{l}100 \\
200 \\
300\end{array}$ & $\begin{array}{l}52 \\
55 \\
84\end{array}$ \\
\hline Richardson and Fordtran (1974) & Duodenal ulcer & 4 & $\begin{array}{r}-30 \\
-15\end{array}$ & $\begin{array}{l}300 \\
300\end{array}$ & $\begin{array}{l}76 \\
49\end{array}$ \\
\hline This study & Normal & 3 & $\begin{array}{r}-32 \\
0\end{array}$ & $\begin{array}{l}200 \\
200\end{array}$ & $\begin{array}{l}67 \\
57\end{array}$ \\
\hline $\begin{array}{l}\text { Richardson and Fordtran (1975) } \\
\text { Henn et al. (1975) }\end{array}$ & $\begin{array}{l}\text { Duodenal ulcer } \\
\text { Duodenal ulcer }\end{array}$ & $\begin{array}{l}3 \\
3\end{array}$ & $\begin{array}{r}0 \\
-30\end{array}$ & $\begin{array}{l}300 \\
100 \\
200 \\
300\end{array}$ & $\begin{array}{l}56 \\
53 \\
60 \\
73\end{array}$ \\
\hline
\end{tabular}

Table 2 Comparison of effects of metiamide and cimeridine on food-stimulated acid secretion ( $n$ o. $=$ nunber of subjects at each dose, or time of dose)

meal resulted in peak blood concentrations of 3 to $7 \mu \mathrm{mol} / 148 \mathrm{~min}$ after the dose, but the levels fell rapidly to approximately $2 \mu \mathrm{mol} / 1128 \mathrm{~min}$ after administration. Cimetidine is thought to be absorbed in the small intestine and it is likely that the rapid absorption was produced by prompt gastricemptying of the $50 \mathrm{ml}$ of fluid instilled $32 \mathrm{~min}$ before the meal.

The rapid absorption and high blood levels of the drug when given before the meal were reflected in a more profound inhibition of early acid output (Table 1) but at this stage post-prandial acid secretion is buffered by the meal itself (LennardJones and Babouris, 1965; Pounder et al., 1976). When cimetidine is taken with a meal, bioavailability of the drug may be prolonged because of slower absorption from the gut. The inhibition of acid secretion might therefore be delayed until late after the meal, when the buffering capacity of the ingested food has been diminished by gastric emptying. Similar absorption curves are likely to occur with post-prandial medication, although this study does not provide data on this point. Clearly, the timing of medication in relation to food may affect the therapeutic efficacy of cimetidine and it needs to be carefully defined in further pharmacological and clinical studies (Pounder et al., 1976).

When cimetidine was administered with the meal, a much greater inhibition of acid output was recorded during the first $16 \mathrm{~min}$ after food (Fig. 7, open circles) than expected from the data on blood level response obtained during the remainder of the study. There are several possible explanations of this apparent discrepancy. Firstly, measurements performed when the rate of acid secretion was changing rapidly may have been subject to experimental error. However, inhibition of acid secretion during the first 16 min after the meal was consistent with the observed relationship of blood level and response in the other subjects who were dosed
$32 \mathrm{~min}$ before food. Moreover, we have not recorded similar discrepancies in other studies using this technique. Secondly, it is possible that the meal did not maximally stimulate acid secretion during the first minutes of the study: there is evidence that cimetidine more easily inhibits basal than stimulated secretion (Henn et al., 1975). The results during the 16 min after the meal in the other group of subjects are against this explanation (Fig. 7, open triangles). Lastly, it is possible that, immediately after intragastric instillation of the drug, a steep concentration gradient exists between the gastric contents and the mucosa, resulting in local absorption of cimetidine. At that time, systemic blood levels would not reflect the concentration of cimetidine in the vicinity of the parietal cells, but this idea needs further experimental testing.

The normal increase of circulating immunoreactive gastrin concentration after a meal was unaffected by cimetidine, indicating that, in common with other histamine $\mathrm{H}_{2}$-receptor antagonists (Mainardi et al., 1974), cimetidine does not inhibit acid output by interfering with the secretion of gastrin.

Cimetidine has been shown to be a reliable and potent antisecretory drug, which is free of unwanted effects in acute studies in man. As cimetidine is a non-thiourea histamine $\mathrm{H}_{2}$-receptor antagonist, it is to be hoped the risk of producing bone marrow depression has been eliminated. Clinical evaluation of the compound is awaited with interest.

We thank the Medical Officer-in-Charge and the staff of the Medical and Pathology Departments, Royal Naval Hospital, Plymouth, for assistance. We are grateful to the Clinical Research Group, Research Institute, Smith Kline and French Laboratories, Welwyn Garden City, for supplies of cimetidine and for arranging the estimation of blood 
cimetidine levels. We are indebted to Ms Helen Houston, dietician, MRC Gastroenterology Unit, who prepared the meals.

\section{References}

Black, J. W., Duncan, W. A. M., Durant, C. J., Ganellin, C. R., and Parsons, E. M. (1972). Definition and antagonism of histamine $\mathbf{H}_{2}$-receptors. Nature, 236, 385-390.

Brimblecombe, R. W., Duncan, W. A. M., Durant, G. J., Emmett, J. C., Ganellin, C. R., and Parsons, M. E. (1975). Cimetidine-A non-thiourea $\mathrm{H}_{2}$-receptor antagonist. Journal of International Medical Research, 3, 86-92.

Burland, W. L., Duncan, W. A. M., Hesselbo, T., Mills, J. G., Sharpe, P. C., Haggie, S. J., and Wyllie, J. H. (1975). Pharmacological evaluation of cimetidine, a new histamine $\mathbf{H}_{2}$-receptor antagonist, in healthy man. British Journal of Clinical Pharmacology, 2, 481-486.

Fordtran, J. S., and Walsh, J. H. (1973). Gastric acid secretion rate and buffer content of the stomach after eating. Journal of Clinical Investigation, 52, 645-657.

Henn, R. M., Isenberg, J. I., Maxwell, V., and Sturdevant, R. A. L. (1975). Inhibition of gastric acid secretion by cimetidine in patients with duodenal ulcer. New England Journal of Medicine, 293, 371-375.

Lennard-Jones, J. E., and Babouris, N. (1965). Effect of different foods on the acidity of the gastric contents in patients with duodenal ulcer. 1. A comparison between two 'therapeutic' diets and freely-chosen meals. Gut, 6, 113-117.

McCance, R. A., and Widdowson, E. M. (1960). Composition of Foods. 3rd edn., HMSO: London.

Mainardi, M., Maxwell, V., Sturdevant, R. A. L., and Isenberg, J. I. (1974). Metiamide, an $\mathrm{H}_{2}$-receptor blocker, as inhibitor of basal and meal-stimulated gastric acid secretion in patients with duodenal ulcer. New England Journal of Medicine, 291, 373-376.

Pounder, R. E., Williams, J. G., Milton-Thompson, G. J., and Misiewicz, J. J. (1976). The effect of cimetidine on 24-hour intragastric acidity in normal subjects. Gut, 17, 133-138.

Richardson, C. T., Bailey, B. A., Walsh, J. H., and Fordtran, J. S. (1975). The effect of an $\mathrm{H}_{2}$-receptor antagonist on food-stimulated acid secretion, serum gastrin, and gastric emptying in patients with duodenal ulcers. Journal of Clinical Investigation, 55, 536-542.

Richardson, C. T., and Fordtran, J. S. (1974). Effect of metiamide, a histamine $\mathrm{H}_{2}$ receptor antagonist, on food stimulated acid secretion in patients with duodenal ulcer. (Abstract.) Gastroenterology, 66, 861.

Richardson, C. T., and Fordtran, J. S. (1975). Effect of cimetidine, a new histamine $\mathrm{H}_{2}$-receptor antagonist, on food stimulated acid secretion in duodenal ulcer patients. (Abstract.) Gastroenterology, 68, 972.

Richardson, C. T., Walsh, J. H., Hicks, M. I., and Fordtran, J. S. Studies on the mechanisms of food-stimulated gastric acid secretion in normal human subjects. (Submitted for publication.) 